\title{
Examination of Thermophysical Processes in the Creation of Metal Layered Compositions
}

\author{
Norkhudjaev F.R, Alikulov. A. Kh, Abdurakhmonov. Kh. Z, Tursunov. T. Kh
}

\begin{abstract}
The article describes the creation of a technological basis for production by casting on gasified models of metal laminates for various metalworking and other tools. The obtained metal layered composition of the type of foundry structural steel - working insert which represent the connection between tool and foundry structural steels. Microstructural studies of metal layered compositions with a solid working element of non-heat-resistant tool steel were carried out. A mechanism has been developed for the formation of a compound of metal layered compositions.
\end{abstract}

Keywords: mathematical model, thermophysical processes, metal layered composition, liquid metal, diffraction method, disordered zone.

\section{INTRODUCTION}

Currently, it is important to increase the economic efficiency of economic sectors to create a new composition of the produced materials; Efficient and economic improvement of technologies for producing products by casting is important for improving the performance of the national economy. In this aspect, purposeful research works, including the conduct of scientific research in the following areas, are among the important tasks:

creation of composite materials using special metal laminated compositions that ensure product quality; development of technologies for the production of metallic layered compositions; improvement of the theoretical and technological bases of heat treatment, contributing to the increase in the strength of the metal laminated compositions; the creation and production of energy- and material-saving new metal laminated compositions based on the latest achievements of science and technology, implying the saving of scarce instrumental materials and an increase in productivity.

The above-mentioned research areas, as well as the results of research carried out according to these research areas, serve as a justification of the relevance of this research.

Despite the constantly developing instrumental technique, to date, very little studied issues related to:

Revised Manuscript Received on September 25, 2019

Norkhudjaev .F.R, Doctor of Technical Sciences, Associate Professor, Head of the Department "Metal Forming" of the Faculty of Mechanics at Tashkent State Technical University. Email: norxojaev. fayzulla 65 @ mail.ru

Alikulov. A. Kh, Assistant of Materials Science department at Tashkent State Technical University. Email:dimonbizon@bk.ru

Abdurakhmonov. Kh. Z, Head of the Department of Mechanical Engineering Technology at Tashkent State Technical University

Tursunov. T. Kh, Senior Teacher of the Department of Mechanical Engineering at Tashkent State Technical University
- The relationship of the structure and properties of liquid metals and alloys;

- interaction of liquid metal with solids.

The problem related to the essence of this work involves tasks related to the production of hard alloys, crystallization of ingots, and the manufacture of layered metal compositions (MSC).

It should be noted that the structure of the liquid metal of the MSC transition zone plays a special role in the process of interaction of the liquid melt (structural steel) with solid inserts used in the manufacture of tool steels, hard alloys and other composites. When considering the structural features, the distribution profiles of various elements in the transition zone, which is a factor determining the compatibility of the insert and the bearing base and the strength of the tool as a whole, knowledge of the structure of the liquid metal is necessary. First of all, the features of its crystallization, in particular the occurrence and dissolution of the cortical zone and the specifics of the development of diffusion processes that determine the distribution curves of the elements in the transition zone. All this, ultimately, forms connections in various MSCs, sets the nature of the stress state. To study the mathematical model of thermophysical processes and the formation of compounds and the stress state in them, it is necessary to study the structural characteristics of the liquid metal, including the specificity of the diffusion mechanism in them.

\section{METHODS}

In the work, modern theoretical and experimental methods of research of metal layered compositions (macro and micro, as well as X-ray diffraction analyzes, etc.) are chosen. Strength and physicomechanical characteristics of metal laminated compositions and products are determined according to the requirements of state standards.

The main methods for studying the structure of liquid metals and alloys are diffraction methods, since they allow us to determine the atomic and molecular structure of solids [1-4].

\section{RESULTS}

Summarizing the results of research [2-4], it can be argued that when metals are melted, not only the interatomic distance changes, but also the coordination number, which determines the number of nearest neighbors of each atom. Metals and alloys that have densely packed lattices with a coordination number of 12 (fcc, hcp) at the melting point and above in the solid state retain 11-12 neighbors for each atom and metals with a

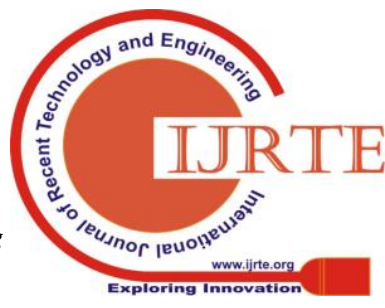


body-centered crystal lattice. Due to the favorable entropy factor, the coordination number 8 remains after melting. So, the short range order in liquid metals remains the same. As far as an ordered zone can spread in a liquid, the answer is given by methods for obtaining a cluster model of a fluid [1, 5-7]. The rest of the fluid is a disordered zone.

Thus, a liquid metal is a combination of two structural components: ordered regions (clusters) and disordered zones, which is the essence of a quasi-polycrystalline model of a liquid. These structural components are organically interconnected: the molecules belonging to the clusters go into a disordered zone and, vice versa. In other words, these mutual transitions are not phase transitions. It was experimentally shown [5-7] that both gases and metals dissolve mainly in the disordered zone.

For the case of MSC, liquid steel, coming into contact with a cold working fluid, forms a cortical zone - a zone of small disoriented crystals. In the literature, the formation of the cortical zone is explained by thermal shock (sudden cooling), which occurs only at the beginning of the crystallization process [1, 5-7]. It is responsible for the structure of the cortical zone only and does not directly affect the further solidification process associated with the removal of the latent heat of crystallization. From the standpoint of a quasicrystalline model of a liquid, it can be argued that the cortical zone is formed mainly by clusters, the rest (rapid freezing of a liquid metal) solidified from clusters and a disordered zone. When a liquid metal interacts with the surface of the insert, on which a bandage can be additionally applied or fixed, the elements of the coating or bandage pass into liquid steel and are unevenly distributed in it. The cortical zone due to the lower solubility of elements in it will be combined with the dissolved elements, most of them are localized in the disordered zone [1, 5-7].

Methods and microprobe techniques (Cameca, Camebax, etc.) $[1,5-7]$, this effect can be caught by the dip in the distribution curves of the elements at the location of the cortical zone. The ratio "cluster part - disordered zone" is temperature-dependent, if the proportional overheating of the liquid metal can achieve a smooth distribution curve of elements in the transition zone. There are general laws that are responsible for the mechanism of formation of MSCs without specifying the various types of metal layered compositions.

In the process of interaction of the melt with a solid insert and depending on the duration (or overheating) of the melt, the following situations are realized:

- the formation of a crust as a result of exposure to thermal shock of a liquid melt of a solid insert, its further complete melting, the interaction of the melt with a solid insert with the formation of a transition zone;

- the formation of a crust with its further preservation or partial melting and the formation of a transition zone due to diffusion processes occurring in the volume between the crust and the insert.

In the first case, there is a direct contact of the solid insert with the melt, through the temporary formation of a crust with the subsequent migration of the liquid phase inside the solid insert. The formation of the transition zone is determined by two factors: the rate of frontal melting and the depth of melt penetration inside the insert.

In the second case, when the crust is preserved (fully or partially) - the direct interaction of the melt with the insert is absent due to the interfering influence of the crust. In this case, the formation of the transition zone is determined either by complete or partial melting of the insert material, or by melting of the intermediate layer, which is preliminarily applied to the surface of the solid insert and has a melting point below the melting point of the insert and the crust.

Consequently, the formation of the transition zone can take place in different conditions of the structural state of the "insert-melt" system, which further determines the differences in the mechanisms of interaction, and therefore in the distribution of elements in the transition zone, stress state, strength and hardness of the transition layer.

The study of the mechanism of diffusion in the transition zone of the MSC in the presence of liquid steel to a certain extent makes it possible to establish a mutual diffusion between the components of the composition.

This structure of the diffusion mechanism and its decisive role in the mechanism of contact formation in transition zones suggests that only this way, by varying the concentrations of the input elements, the temperature and duration of the process, can we achieve a given phase composition in the transition zone and eliminate the appearance of undesirable (fragile) intermetallic phases.

Thus, the study of the mechanism of diffusion in the transition zone MSC in the presence of liquid steel to a certain extent will provide an opportunity to assess the mutual diffusion between the components of the composition.

Direct physical process occurring at the interface of the insert - liquid steel, is diffusion. The term mass transfer is often used in the literature, but this is the same diffusion, only occurring with the participation of the liquid phase [2-7].

In theoretical terms, to describe the diffusion coefficient in liquid metals, it is necessary to have a certain physical model of the diffusion process and, accordingly, specify the values of the elementary displacements of atoms and the time $(\tau)$ for which this displacement occurs. As it follows from a large number of experimental and theoretical works on diffusion, the presence of a new mechanism in a liquid compared to solids, as represented by thermal motion, easily manifests itself in a sharp increase in the diffusion coefficient during melting [2].

The density during melting of metals varies little, and for metals such as antimony and bismuth, even increases. The diffusion coefficient, in contrast to density, increases by five to six orders of magnitude due to the entry into force of a new group mechanism of displacement.

The presence in the liquid of the diffusion mechanism also explains the fact that the diffusion coefficient of all liquid metals near the melting point falls within a narrow range of values of $10-4-10-5 \mathrm{~cm} 2 / \mathrm{s}$, while for solid metals that are also near the melting point, it

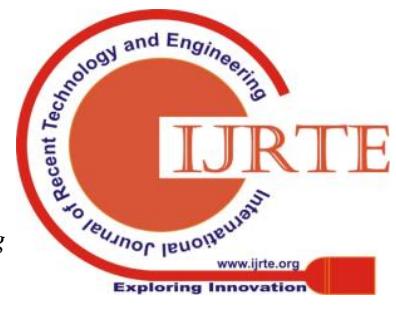


significantly less and varies greatly from metal to metal.

In [2], a formula is proposed for calculating the self-diffusion coefficients in metals from the magnitude of the fluctuations of the first coordination number.

It is assumed that the relative root-mean-square fluctuation of the first coordination number is equal to the relative root-mean-square fluctuation of the free volume inside the first coordination sphere V1, an arbitrarily chosen atom.

$$
\sqrt{\frac{\overline{\Delta v_{c b}^{2}}}{v_{1}}}=\sqrt{\frac{\overline{\Delta z_{1}^{2}}}{z_{1}}},
$$

where $v_{1}$ and $z_{1}$ - are respectively the free volume and the coordination number of the first coordination sphere, $\overline{\Delta v_{c B}^{2}}$ and $\overline{\Delta z_{1}^{2}}$ - are respectively the fluctuations of the free volume and the first coordination number.

To calculate the self-diffusion coefficient, it is assumed that the radius of the diffusing atom in the liquid metal is equal to the metallic radius of Goldschmidt and that the radius of the first coordination sphere differs little from the double metal radius. Then

$$
D=0,15 \frac{k T}{h}\left(\delta z_{1}\right)^{2},
$$

Where D - is the diffusion coefficient, $\mathrm{k}$ - is the Boltzmann constant, $\mathrm{h}$ - is the Planck constant, $\mathrm{r}$ - is the radius of the first coordination sphere. Relative root-mean-square fluctuation of the first coordination number:

$$
\delta z_{1}=\sqrt{\frac{\overline{\Delta z_{1}^{2}}}{z_{1}}}
$$

The coefficients D calculated by formula (2) for a number of low-melting metals show satisfactory agreement with the experimental values, although for some metals ( $\mathrm{Sn}$, $\mathrm{Hg}, \mathrm{Au}$ ) the differences reach 2-3 times.

According to the author, these differences are mainly revealed by the difficulty of clear definition $\left(\delta z_{1}\right)^{2}$.

The results of diffraction studies of iron-carbon melts with a carbon content of $0.2 ; 1.50 ; 3.0$ and 3.85 wt. $\%$ Near the liquidus line showed that the radius of the first coordination sphere and the first coordination numbers were equal [2]:

$\begin{array}{llc} & \mathrm{r}_{\max } & \text { Cordination number, K } \\ \text { Pure iron } & 2,6 & 11,7 \\ \mathrm{Fe}+0,2 \% \mathrm{C} & 2,6 & 11,7 \\ \mathrm{Fe}+1,5 \% \mathrm{C} & 2,45 & 8,7 \\ \mathrm{Fe}+3,0 \% \mathrm{C} & 2,5 & 4,9 \\ \mathrm{Fe}+3,85 \% \mathrm{C} & 2,50 & 9,1\end{array}$

As can be seen from the above data, with an increase in the carbon content, there is a tendency for $r$ to change (an increase in the chemical bond level in the melt) and a decrease in the coordination number $Z$. However, $Z=4.9$ for $\mathrm{Fe}+3.0 \% \mathrm{C}$ alloy is in doubt.

At the same time, there is a clear downward trend in $\mathrm{Z}$ with increasing carbon content. The pronounced concentration dependence of $\mathrm{Z}$, as well as the temperature dependence of $\mathrm{Z}$, do not make it possible to clearly estimate the values of the coordination numbers, and hence the values of the relative mean-square fluctuations of these numbers. However, for the first time, the diffusion coefficient or (self-diffusion) was calculated taking into account the structural features of the liquid metal. Quasi-polycrystalline model of inhomogeneous melts [2], according to which the melts are a combination of two structural components: clusters (microgroups with an ordered arrangement of atoms close to that in crystalline bodies) and a disordered zone with a chaotic (quasi-gas) and, as a rule, looser arrangement of particles forming a continuous three-dimensional cellular network in melts enveloping clusters.

The diffusion conductivity of the melt is the sum of the diffusion conductivities of the cluster zone and the disordered zone:

$D=\psi_{\kappa л} \cdot D_{\kappa л}+\psi_{p} \cdot D_{p}$,

where D - is the effective (apparent) diffusion coefficient;

$\psi_{\kappa л}$ and $\psi_{p}$ - relative shares of clusters and disordered melt zones, $\psi_{\kappa л}+\psi_{p}=1$;

$D_{\kappa л}$ and $D_{p}$ - partial diffusion coefficients of atoms of the materials used for the cluster zone and the zone of softening.

Depending on the magnitude of solubility in solid and liquid iron, the authors [1, 2-4] identified three groups of impurities:

- group №1 - impurities with unlimited solubility, both in solid and in liquid iron;

- group №2 - impurities with limited solubility in solid iron and unlimited - in liquid iron (solvent);

- group №3 - elements with limited solubility, both in solid and in liquid iron (solvent).

Below are the values of $\mathrm{D}$ and the depth of penetration of elements - L in the liquid iron. The depth of diffusion of elements in liquid iron was estimated by the formula.

$L=2 \sqrt{D \tau}$

where D - is the diffusion coefficient, $\tau$ - is the interaction time.

Such a structure of the diffusion mechanism and its decisive role in the mechanism of contact formation in transition zones suggests that only by varying the concentrations of the input elements, the temperature and duration of the process can a given phase composition be obtained in the transition zone and the appearance of

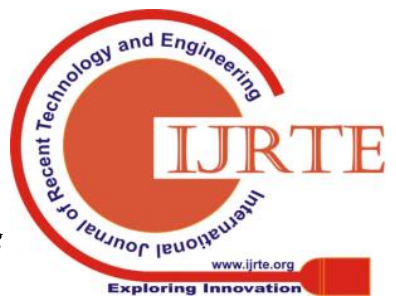


undesirable (fragile) intermetallic phases can be excluded.

\section{DISCUSSION}

The difference in the diffusion rate of the dissolved elements in the liquid steel is determined by the microheterogeneity of its structure. Therefore, transportation (mass transfer) of alloying elements in liquid iron, steels is determined by two diffusion mechanisms:

- through clusters having a quasicrystal structure similar to a crystalline body;

- in a disordered zone with a random arrangement of atoms - i.e. in the quasi-gas component.

The above equation (5) takes into account the influence of the two structural zones in the liquid melt, but does not take into account the different solubility of the elements in these two zones. It corresponds to the extreme case of the same solubility of elements in different structural zones, i.e.

$$
\mathrm{C}_{\text {кл }}+\mathrm{C}_{\text {раз }}=1 \text { и } \mathrm{C}_{\text {кл }}=\mathrm{C}_{\text {раз }}=0,5,
$$

Where Скл and Сраз - are respectively the solubility of elements in the cluster and disordered zones.

Condition (6) implies the same probability of dissolution of elements in clusters and in a disordered zone. That equation (6) was universal, i.e. took into account the different solubilities in eliminate in it the implicit content of the components Скл = Сраз $=0,5$ and multiply each of the members of its right side by the true solubilities Скл and Сраз. As a result, we have the equation.

$$
D=D_{\kappa л} \cdot \psi_{\kappa л} \cdot C_{\kappa л} / 0,5+D_{\text {раз }} \cdot \psi_{\text {раз }} \cdot C_{\text {раз }} / 0,5
$$

The partial determination of the coefficients Dкл and Dраз presents great theoretical and experimental difficulties; therefore, the calculation of D is carried out as follows.

For diffusion of dissolved elements in liquid metals, the Stokes - Einstein equations are used [8].

According to their theory of viscosity of liquids, the diffusion coefficient $\mathrm{D}$ and the resistance to the movement of particles in a liquid $\mathrm{C}=$ are related by the simple relation.

$$
D=\frac{k T}{C}=\frac{k T}{6 n \eta r}
$$

Then

$$
\begin{gathered}
D=\frac{k T}{6 n \eta r_{\ni}}, \\
D_{0}=\frac{k T}{6 n \eta r_{\ni}^{0}},
\end{gathered}
$$

For the diffusion of dissolved elements in the liquid metal and for the self-diffusion of the metal-solvent, the following designations are used in ratios (9) and (10):

$\eta$ - liquid metal viscosity

$\mathrm{T}$ - absolute temperature

$\mathrm{k}$ - Boltzmann constant,

$$
\text { rэ - effective (apparent) atom radius of dissolving }
$$
elements,

- effective radius of solvent atoms.

By dividing (9) by (10) we get:

$$
\frac{D}{D_{0}}=\frac{r_{\ni}^{0}}{r_{\ni}},
$$

From where

$$
D=D_{0} \frac{r_{\ni}^{0}}{r_{\ni}}
$$

The value of $r$ and is determined by the equations, similar to equation (7). Based on the fact that the dissolved element, which is in the disordered zone, moves as separate atoms, and the element that is part of the clusters moves with them, we get:

$$
r_{\ni}=r_{a} \cdot \psi_{\text {раз }} \cdot C_{\text {раз }} / 0,5+r_{\kappa л} \cdot \psi_{\kappa л} \cdot C_{\kappa л} / 0,5
$$

For self-diffusion processes, when the condition Скл $=$ Сраз $=0,5$ is true, we get:

$$
r_{\ni}=r_{M e} \cdot \psi_{\text {раз }}+r_{\kappa л} \cdot \psi_{\kappa л} \text {, }
$$

where rMe - is the radius of the metal atom - solvent; гкл - the average size of a cluster of metal - solvent; $\mathrm{ra}$ - is the atom radius of the element being dissolved. Substituting (10) and (11) into (9), we get:

$$
D=\frac{r_{M e} \cdot \psi_{\text {раз }}+r_{\kappa л} \cdot \psi_{\kappa л}}{r_{a} \cdot \psi_{\text {раз }} \cdot C_{p a 3} / 0,5+r_{\kappa л} \cdot \psi_{\kappa л} \cdot C_{\kappa л} / 0,5}
$$

To calculate D, it is necessary to determine the values of гкл, Сраз, Скл, чраз, чкл.

In accordance with [9], the cluster radius is estimated by the expression:

$r_{\kappa л}=\left(\beta \frac{\Delta H_{u c n}}{\Delta H_{n л}}-1\right) \frac{d}{2}$

where $\beta$ is the packing factor;

$\beta=1$ for a simple cube and a body-centered cubic crystal lattice (BCC);

$\beta=0.5$ for a face-centered cubic crystal (FCC) and hexagonal tightly packed (HP) structure;

$\Delta H_{u c n}, \Delta H_{n л}$ - latent heat of evaporation and melting; $\mathrm{d}$ is the interatomic distance in the crystal. 
In particular, for liquid iron and steel at their melting point, the cluster radius is $r_{\kappa l}^{(\mathrm{Fe})}=23 A^{0}$.

The proportion of the disordered zone, according to S.Z. Bokshtein [10], can be estimated by the formula

$$
\psi_{\text {раз }}=3 \sqrt{\gamma d / E}\left(2 r_{\kappa л}+\sqrt{\gamma d / E}\right)
$$

Where E - is the modulus of elasticity;

$\gamma$ - is the surface tension coefficient at $\mathrm{T}_{\text {melt }}$;

$\mathrm{d}$ - is the interatomic distance in the crystal.

The ordered area $\psi_{\text {кл }}$ is calculated according to the ratio

$$
\psi_{\text {кл }}=1-\psi_{\text {раз }}
$$

It should be noted that $\psi_{\mathrm{pa}}$ is clearly correlated with the ratio of changes in the volume of the metal during melting and, in the overwhelming number of cases, this change can be taken as the value of $\psi_{\text {раз }}$ [11].

For liquid iron at the melting point and higher $\psi_{\text {раз }}=$ $4,7 \%$, respectively $\psi_{\text {кл }}=95,3$. Take $\mathrm{r}_{\mathrm{Me}}=1,28 \mathrm{~A}$ [12-14] and count:

$$
r_{\ni}^{0}=1,26 \cdot 0,0047+23 \cdot 0,953=22 \mathrm{~A}^{0}
$$

Since the values of $\mathrm{r}_{\text {кл }}$ and $r_{э}^{0}$ are quite close, it can be concluded that the process of self-diffusion in the liquid gland is mainly carried out by self-diffusion through a cluster mechanism.

The values of $\mathrm{C}_{\text {кл }}$ and $\mathrm{C}_{\text {раз }}$ can be determined on the basis of ideas about the different solubilities of the elements in the clusters and the disordered zone. Since clusters have a crystalline structure, the solubilities of the elements in them are approximately equal to their solubilities in a solid.

Depending on the amount of solubility in solid and liquid iron, three groups of elements can be distinguished.

The first group includes elements that have unlimited solubility, both in the solid and in the liquid state, i.e.

$$
\mathrm{C}_{\text {раз }}=\mathrm{C}_{\text {кл }} ; \mathrm{C}_{\text {раз }}+\mathrm{C}_{\text {кл }}=1 \text { и } \mathrm{C}_{\text {раз }}=\mathrm{C}_{\text {кл }}=1
$$

The second group includes elements characterized by unlimited solubility in liquid and limited solubility in solid iron.

The third group includes elements with limited solubility, both in solid and in liquid iron.

All data on the solubility of elements in liquid iron at $1600^{\circ}$ $\mathrm{C}$ can be taken from the phase diagrams of the Fe element, given in $[15,16]$.

For example, we give the calculation of $\mathrm{D}$ for cobalt by the formula (15) for which $\mathrm{C}_{\text {раз }}=\mathrm{C}_{\mathrm{кл}}=0,5$ (unlimited solubility) $D_{F e}^{2}=1,7 \cdot 10^{-6} \mathrm{~cm}^{2} / \mathrm{c}$ at $1600^{\circ} \mathrm{C}$.

$$
D_{C o}=1,7 \cdot 10^{-6} \frac{1,26 \cdot 0,047+23 \cdot 0,953}{(1,25 \cdot 0,047+23 \cdot 0,953) 0,5 / 0,5} \approx 1,8 \cdot 10^{-6} \mathrm{sm}^{2} / \mathrm{s}
$$

Hence, the estimated depth of penetration of Co into liquid iron for conditions $\mathrm{T}=1600^{\circ} \mathrm{C}$ and $\tau=10 \mathrm{~s}$, calculated by formula (16)

$$
L=2 \sqrt{1,8 \cdot 10^{-6} \mathrm{cM}^{2} / c \cdot 10 c}=8,48 \cdot 10^{-3} c M=84,8 \text { мкM }
$$

Thus, approximately equal depths of penetration mean the closeness of the velocities of the diffusing elements in the process of their dissolution. This explains the occurrence of flows of soluble elements in liquid steel, which means a high degree of their interaction with each other and the effect of the melt with the possible formation of new phases, i.e. implementation of the necessary conditions for the occurrence of reactive diffusion.

With sharp differences in the penetration depth L, and hence the diffusion rates $\tau$, the probability of meeting different atoms and clusters will be very low and the formation of new phases separated from the melt is unlikely. The formation of these phases is possible only on the surface of a solid-liquid interface and is not of a single nature $[17,18]$.

\section{CONCLUSION}

The following conclusions can be made on the basis of the research:

1. The mechanism of interaction of liquid metal with the surface of the insert in metal layered compositions was revealed. These mechanisms will be useful in the future when creating metallic laminated compositions.

2. Identification of the mechanism of diffusion in the metal layered compositions makes it possible to assess the mutual diffusion between the components of the composition.

3. The conditions for the formation of the transition zone between the components of the metal layered compositions. These are important when forming metallic layered compositions.

\section{REFERENCES}

1. Вайнгард У. Введение в физику кристаллизации металлов. М.: Мир, 1967.- 170 с.

2. Лисовский А.Ф. О механизме массопереноса жидких металлов в спеченных композиционных материалах // Инж. - физ. журнал. Москва, 1979. - №6. - С. 977-979.

3. Хрущев Б.И. Структура жидких металлов. - Ташкент Фан, 1979. $-111 \mathrm{c}$.

4. Norknudznaev F. R., Nazarov A. M., Koveshnikov S. V., Mavlonov Sh. A., Khurbanbaev Sh. Z., Ataullaev A. O. The fiber-optical sensor for chromate-graphic measurements // International Journal of Advanced Research in Science, Engineering and technology.-India, 2016. - Vol.3, Issue 8. - pp. 2463-2467.

5. Архаров В. И., Новохатский И. А., Ершов Г. С., Коваленко А. М. Диффузия водорода в расплавленном железе // ДАН СССР.- 1970. - Т.190.6- С. 1122-1127.

6. Новохатский И. А., Архаров В. И. Определение относительных долей структурных составляющих металлических расплавов // ФММ. - М., 1971.- Т.31, .- С. 1263-1267.

7. Новохатский И. А., Архаров В. И., Ершов Г.С., Келупко В. С. О распределении растворенных элементов между структурными составляющими расплавленого железа // ДАН СССР. - М., 1970. T.194, 4. - C. 1402-1410.

8. Мелвин - Хьюз Э. А. Физическая химия. - М.: Изд. ИЛ, 1962. - 1148 c.

9. Клейнер М. К. Локальные тепловые потоки в замкнутом пространстве с переменной структурой стенок // Черная металлургия: Изв. ВУЗов - Москва, 1973. - №4. - С.153.

10. Бокштейн С. 3. Строение и свойства металлических сплавов. - М. Металлургия, 1971. - 496 с. 


\section{Examination of Thermophysical Processes in the Creation of Metal Layered Compositions}

11. Арсентьев П.П., Коледов Л. А. Металлические расплавы и их свойства. - М.: Металлургия, 1999. - 376 с.

12. Вайберг В.К., Соседов В. Н., Кушнир А. Н. Исследование роста трещин методом акустической эмиссии // Дефектоскопия 1975.-№3. - C. $127-129$.

13. Иванова В. С., Маслов Л. И., Параев С. А. Акустическая дагностика разрушения стали // Сб. докл. IX Всесоюзн. акустич. конф. Секция Б, 1977 М.: Акустический институт, 1977. - С 181-184.

14. Лошак М. Г. Прочность и долговечность твердых сплавов. Киев: Науковадумка, 1964. - 328 с.

15. Свойства элементов: Справочник / Под. ред. Г.В. Самсонова - М.: Металлургия, 1976. - 476 с.

16. Шанк Ф. А.Структура двойных сплавов.- М.: Металлургия, 2014.-232 c

17. Норхуджаев Ф. Р. Разработка теоретической и технологической основы производства и термической обработки металлических слоистых композиций. : Дис...Д-ра. техн.наук. - Ташкент, 2016. $210 \mathrm{c}$

18. Norknudznaev F. R., Nazarov A. M., Yakubov L. E. Sintered powder composition on the basis of Mo - TiC. India. International Journal of Advanced Research in Science, Engineering and technology, 2016. Vol.3, Issue 7, July. pp. 2347-2350. 